\title{
On being local and being successful in Korea: Tesco and E-mart ${ }^{1}$
}

\author{
Woohyoung Kim \\ Graduate School of Technology Management, Kyunghee University, Korea \\ Sanghyup Shin \\ Graduate School of Technology Management, Kyunghee University, Korea \\ Alan G. Hallsworth \\ Faculty of Business and Law, University of Portsmouth, UK
}

\begin{abstract}
Tesco withdrew from the Korean market in September 2015. The withdrawal of Tesco has not generally been seen as being due to management failure, but, instead, as a strategic reallocation of resources by Tesco in the UK. Yet there may still be more to understand about this development. The tale of Tesco's arrival in and departure from Korea has not ended. We consider the relative performance of Tesco (Homeplus) stores and those of rival E-Mart. We find that, in attempting to be authentically local, Tesco may have hampered its own long-term success in an important overseas market. In an empirical study we utilised the Logit model to contrast selection factors employed by local consumers in respect of both Tesco/Homeplus and E-Mart. Our analysis reveals that product range (including Private Brands), store accessibility, and convenience were the main factors on which consumers discriminated between these rivals.
\end{abstract}

\section{Introduction}

Since the pioneering work of Scott (1970) geographers have paid increasing attention to retailing as a major sub-sector of the Service industries. Indeed, the UK retail sector currently has a turnover of some $£ 350$ billion per annum and employs around 2.8 million workers. Increasingly, observers have noted the implications of the increased size, scale, and power of the top retailers. 30 years ago, Wrigley (1988) noted that retail businesses ranked among the largest of enterprises. WalMart of the USA is often cited as the largest privatesector employer in the world - making retailing increasingly difficult to ignore.

Stockmarket-listed businesses face a perpetual search for new markets in order to maintain

1 The Consumer survey in this paper was carried out prior to Tesco's sale of Homep lus in January, 2015.

The authors are grateful to the editor and to the anonymous referees for their gene rous insights. 
even modest growth and profit targets. This can lead to mergers or diversification or to ventures into overseas markets. In this paper we consider South Korea where the latter trends have proved to be remarkably interesting. Using an empirical technique well established in Britain, we seek insights on how Koreans actually use rival stores and what they think of them. This reveals important contrasts in local patronage between leading domestic retailer E-Mart and its foreign-owned rival Tesco. We detect advantages accruing to systems that permit local products to be locally supplied. The yet wider message is that the retail sector remains characterized by constant and often unpredictable change.

\section{Retailing and globalisation}

There is a notable literature on globalisation of businesses operations: including retail (Akehurst and Alexander 1996). However, it has been dominated by research on manufacturing: for example on Fordist versus Flexible production regimes (Burrows et al 1992). Fordism demonstrates the longstanding tendency of manufacturers to move routine production overseas to lower-cost environments (Dicken 1986) and this included China after it joined the WTO. As noted, the service sector in its search for growth often turns not just to overseas sourcing but overseas selling. This is rarely uncomplicated and our interest lies with a particular subset of retail globalisation which links to local authenticity. So, for example, for many who desire an Apple i-phone it may not matter if that product was invented or manufactured in the USA or in China. Conversely, the Trump Presidency has brought to the fore the topics both of repatriation of production and of 'genuine US content'. In retailing an overseas 'flagship' store (Nobbs et al 2012) for, say, Gucci, is not likely to generate controversy since it may safely be ignored by most whilst greatly welcomed by a privileged few consumers. 
Apple (as with Singer Sewing machines of an earlier Century) and Gucci may quite possibly achieve global acceptance but other businesses can face problems - sometimes unanticipated. In 2018, the death in Sweden of the founder of IKEA drew attention to the countries where it had succeeded. These were mostly Western countries with a preparedness to embrace both very large stores and the concept of DIY. Yet the basic concept of DIY faced social/cultural resistance in Chile as Bianci (2008) discovered. We do not have space to cover the literature on social/cultural/ differences between countries (covered in Wong et al 2015). However, where such differences or 'distances' are small - as between Canada and the USA - then, as demonstrated by Arnold (1997) and Daniel and Hernandez (2017), it is not surprising that US mega-corporations dominate Canadian retailing. In some cases, as with iconic Hudson's Bay Department stores, the locals may not even be aware that a landmark Department Store has fallen under foreign control (not uncommon: Hallsworth 1991a). Indeed many British shoppers are probably unaware that popular Primark is controlled by the Canadian Weston group. Here we accept the truism that the expansion of food/ fast-moving consumer goods retailers into overseas markets is most likely to be problematic. Especially if, as is typical with food, account must be taken of important local social/cultural/ preferences. This is where the local meets the global (Bell and Valentine 1997). Many local people can be affected if local suppliers of basics such as food are replaced by unfamiliar Western retailers: as happened in some parts of South-East Asia when markets were liberalised in the 1990s (Kim and Hallsworth 2013). The moststudied of the 'invading' new stores have tended to be (very) large scale grocery stores: though the terminology used varies. The three most prominent operators of such stores are WalMart (supercenters) Tesco (superstores) and Carrefour (hypermarkets). That said, 
WalMart entered Canada by buying Woolco with its smaller 'discount' format stores and the UK by purchasing existing operator ASDA. In fact, all three firms currently operate from formats of different sizes - most notably Tesco. Our concern here is with the very largest stores and, as there are no accepted store type definitions, we adopt the terminology (above) that the retailers themselves use. Also, for all three retail chains, diversification into overseas markets has involved a mixture of successes and failures. For example, WalMart entered and soon left Germany - where Gerhard and Hahn (2005) found that locals preferred familiar products offered by ALDI. Also, Carrefour entered and left England and Wales and Tesco entered and left the USA. One country that was a target for all three is South Korea. South Korea is an attractive case study since the criticism that retailing is under-theorised has been addressed by retail-based research in Korea. As in many such 'host' countries, the received wisdom was that superstores or hypermarkets were a successful 'Western' format that would probably overwhelm local rivals leading to instant and profitable, success. The experience of WalMart and Carrefour in South Korea, however, was one of very rapid failure. The details of how that came to be the case for those two big players, but not the third, Tesco, is what concerned researchers.

\section{Tesco in Korea: Are you local?}

For reasons thoroughly analysed (Coe and Lee 2006, 2013; Coe and Wrigley 2009, 2017 ; Wood Coe and Wrigley 2016; Coe Lee and Wood 2017) Tesco thrived in Korea by adopting 'Glocalisation'-globalizing activities whilst attempting to be as 'Korean' as possible in their actions. Their signal contribution was that Tesco had become 'embedded' in a way that WalMart and Carrefour had not. Whereas their rivals imposed their elsewhere-successful formats upon Korea, Tesco acted more subtly. Their efforts towards embeddeness may 
explain why Tesco left Korea only after a much longer and more impactful stay.

Embeddeness/ Glocalisation led Tesco to team with powerful Samsung, to use the name Homeplus rather than Tesco, and to employ a Korean Chief Executive. That said, he later went on to court controversy in a rather un-Korean manner as did his successor in 2013 (Coe et al 2017). This is not irrelevant in that it openly revealed that Homeplus was a Tesco operation and not truly Korean as many may have thought. That said, Homeplus appeared to assert Korean cultural values by devoting space to Community and educational uses. Yet, in 2015, Tesco sold off its Korean operations to local investors. Coe et al (2017) argue that Tesco was responding to domestic tribulations in the UK and sold its Korean business in order to offset substantial trading losses at home: a view with which we concur.

Here we focus on the aspects of the Korean context (see also Pattnaik and Lee 2013) to which Coe et al (2017) alluded by identifying several local difficulties suggesting that Tesco may not have been an entirely unwilling vendor. They faced rising Unionisation and regulatory reform and the reaction of established powerful rivals notably E-Mart. Clearly there was pressure opposing Tesco - a mindset largely discouraged in Europe by EU prointegration mindsets. Their stability disrupted Korean rivals responded to Homeplus. Note that Ekinsmyth et al (1995) discussed both embeddedness and stability whilst calling for Geographers to undertake more study of how powerful businesses behave. Here we will look at how Tesco and its major Korean rival E-Mart performed as direct competitors.

A related point is this: did the provenance of some Homeplus stores influence how they were used? Though Tesco grew steadily, they did not build every single store from the ground up - some stores were acquired from the failed Carrefour venture. Were they over- 
sized for Tesco's later purposes? Maybe so, given the Community uses to which apparentlysurplus floorspace was put. Whatever, Tesco entered the Korean market with a fifty-fifty joint venture with Samsung C\&T Corporation in 1999. As above, Tesco made substantial efforts at (g)localization via joint investment rather than attempting direct entry: the process that, in Korea, failed for Carrefour and Wal-Mart. As a result, Tesco Homeplus achieved good trading performance for 15 years and became competitive enough to challenge the industry leader, E-mart. Tesco/Homeplus grew (see also Table 3 in Coe et al 2017) from two stores in 1999, to 141 and staff numbers increased from 800 to 26,000 - becoming Korea's second largest retail corporation - wholly owned by Tesco by 2011 . We cover the Korean retail market in the next section. Yet Tesco eventually sold out to Korean private equity fund, MBK partners - but that still leaves the topic of how consumers actually responded to Tesco/Homeplus. This moves away from analysis of the investment/divestment process focused on to structural and legal obstacles, localization strategy, difficulties in the entry process, etc. Indeed, behavioural factors/local preferences have often been under-played (see Goldman et al 1999).

\section{Retail change in Korea}

Korean retailers faced major changes after the opening of the distribution market in 1996.

Subsequently, as confirmed by Coe et al (2017), both the number and sales volumes of small and medium sized businesses (notably traditional retail markets) in Korea decreased rapidly at the expense of what Koreans call Super-Supermarkets (SSMs). Internet, TV and home shopping all showed sales increases as the system restructured - probably with largely 'invisible' job losses in traditional store sectors. This is not irrelevant since, in Britain, Tesco and others portray new store openings as creators of (usually 300) 'new' jobs and thus 
inherently beneficial. Some suggest that, in the present economic climate in the UK, Tesco have actually shed 10,000 jobs since current CEO Lewis took over. Back in Korea, overall sales of retail businesses showed a gradual increase: from 143 billion US dollars in 2007 to 215 billion US dollars in 2011(Korea Statistics, 2013). The largest stores comprised some $17 \%$ of the total retail industry with around 36.4billion (US \$) as of 2011 (Korea Statistics, 2013). 
Table 1 Sales volumes of Retail Business in Korea by format (2005-2011)

\begin{tabular}{|l|l|l|l|l|l|l|l|}
\hline & 2005 & 2006 & 2007 & 2008 & 2009 & 2010 & 2011 \\
\hline Traditional Market & 23.6 & 21.6 & 19.5 & 19.3 & 19.1 & 18.5 & 18.2 \\
\hline $\begin{array}{l}\text { Large Discount } \\
\text { Store }\end{array}$ & 20.5 & 22.9 & 25.8 & 27.6 & 28.8 & 27.2 & 31.1 \\
\hline Department Store & 15.1 & 10.6 & 11.5 & 12.1 & 13.2 & 13.8 & 14.4 \\
\hline $\begin{array}{l}\text { Super Market } \\
\begin{array}{l}\text { Super-Super } \\
\text { Market) }\end{array}\end{array}$ & 16.4 & 16.8 & 18.5 & 20.9 & 23.2 & 26.3 & 29.0 \\
\hline Convenience Store & 3.1 & $(2.0)$ & $(2.3)$ & $(3.0)$ & $(3.6)$ & $(4.3)$ & $(5.3)$ \\
\hline Non-Store Retailing & 13.2 & 12.3 & 12.4 & 12.8 & 13.9 & 19.6 & 22.1 \\
\hline
\end{tabular}

Source: Korea Statistics (2013), SMBA (2012), Korea Chain Store Association (2011).

As of 2011, the Big 3 large store operators in Korea (E-mart, Homeplus, and Lotte Mart) had total sales of around 25.3 billion US dollars and around $86.6 \%$ of the market (SMBA, 2012; http://store.emart.com, http://corporate.homeplus.co.kr). Contextually, as of December 2013, there were a total of 136 Homeplus locations and the average size of the shops was $38,507 \mathrm{~m}^{2}$. E-mart, had 146 locations with an average shop area of $10,300 \mathrm{~m}^{2}$ (The Yearbook of Retail Industry, 2013). According to the Korea Statistics Office (http://kostat.go.kr), the sales, as of December 2016, for the two corporations were 13 billion US dollars for E-Mart and 6.8 billion US dollars for Homeplus.

\section{Prior Research on inter-store competition}

One prominent use of applied geography has been to employ large databases and geodemographics to improve location planning for new stores. Such expertise has been a key driver of the growth in market share held by the largest - most-professional - retailers. Geographers, both in University Geography Departments (eg GMAP at Leeds) or in Research Institutes founded by Geographers (eg IRS, Stirling University, OXIRM, Oxford, CSCA, Toronto) 
are central to this process. Informed by store location geographers, UK Tesco stands out for its use of geodemographics to assist in building the right size of store in the best location. However we have noted that in Korea Tesco acquired some stores that were sub-optimal: for example, one is 'embedded' in the 2002 World Cup Stadium.

Coe et al have researched how Tesco entered Korea whereas we consider at-store performance - how Koreans reacted to Tesco - by comparing rival store attributes such as location, and consumer preference criteria. Indeed Wrigley, who has researched retail internationalization (eg Durand \& Wrigley, 2009) has also turned to detailed analysis of more micro-locational issues (see Wrigley and Dolega 2011). Store-based 'impact' factors that are frequently found to be important include product price and quality (Arnold, 1997). Accessibility, too, is significant but may be under-estimated once the store choice decision is made (Hallsworth 1991b) while Kim and Kim (2013) show that Korea's traditional retail formats need better accessibility in order to remain competitive. Convenience is very significant: consumers even stress convenience as a factor when shopping online. We do not pursue online shopping but note that Coe et al (2017) identify this, too, as a pressure on Tesco in Korea. So, attributes such as convenience but also store layout, facilities, and the general physical environment are regularly identified as important.

\section{Research method}

We wished to discover more about the impact of the Tesco-owned Homeplus stores trading in Korea. The topic of Impact Studies was a theme at the British Geographers' Annual Conference as long ago as 1981. Utilising variables identified in past research, data were collected through a questionnaire - the familiar survey of shopping patterns often 
undertaken by market research companies. We surveyed residents of Korea's two main capital regions (Seoul and Kyeonggi) where around half of Korea's domestic population resides. We contrasted reactions to, and usage of, rival stores run by E-mart (78) and Homeplus (63). The survey process collected 209 and 212 questionnaires in Gangseogu, Seoul and Euijeongbu, Kyeongido respectively and was conducted between April 10 and April 2015, through a random sample of people aged over 20 years and by employing a professional research corporation. A total of 421 usable responses were obtained. The questionnaires took store ownership (E-mart or Homeplus) as the dichotomized dependent variable and demographic characteristics were used as independent variables. We also recoded average monthly number of store visits, monthly average purchase amount and selective attributes of these large stores. Essentially, we wanted to know how, and especially why, one chain might be preferred to the other.

\section{Model}

Akinci, Kaynak, Atklgan \& Aksoy (2007 p 538) see logistic regression as a relevant technique "...for modeling and discrimination problems in marketing. Since it has alternative data distribution assumptions, it generates more appropriate findings in terms of model fit and the correctness of the analysis". Accordingly, the Logit model was chosen from among the non-linear regression models in which the dependent variables have bivariate characteristics. The binary Logit model is represented as

$\operatorname{Pr} o b(y=1 \mid x)=\frac{\exp (x \beta)}{1+\exp (x \beta)}=\Lambda(x \beta)$ where the link function indicates the cumulative standard logistic probability distribution function. In this study, since the dependent variable is whether the consumer did/did not choose a store, the binomial logistic regression analysis 
is an appropriate statistical estimation technique. Essentially, the object variables are 0 (Homeplus) and 1 (E-mart), and the prediction value is 0 or 1.

\section{Data Analysis}

The general characteristics of the sample responses to the survey are listed in table 2 and are as follows. 212 people (50.4\%) preferred E-Mart and on average they visited 3.45 times per month. The average purchase amount per visit was 43,100 won (37.5 dollars US).

Regarding gender, the majority were females: 298 (70.8\%) and there were 338 married people (80.3\%). There were 234 people under 30 (55.6\%), while the number of people over 40 years old was 187 (44.4\%). Regarding the average monthly income per family, there were 184 people with an income of under $\$ 3,636(43.8 \%)$. 
Table2 Description of derived Variables

\begin{tabular}{llll}
\hline Division & & Frequency/Mean & Ratio(\%)/Std. \\
\hline \multirow{2}{*}{ Mall } & E-mart $=1$ & 212 & 50.4 \\
Frequency of visit & Homeplus $=0$ & 209 & 49.6 \\
Purchase amount & per Month & 3.45 & 2.81 \\
Gender & Men=1 & 4.31 & 0.99 \\
& Women $=0$ & 123 & 29.2 \\
Marital Status & Married $=1$ & 298 & 70.8 \\
& Unmarried & 338 & 80.3 \\
& $20-30=1$ & 83 & 19.7 \\
Age & $31-40=2$ & 80 & 19.0 \\
& $41-50=3$ & 154 & 36.6 \\
& $51-60=4$ & 125 & 29.7 \\
& 60 and greater $=5$ & 93 & 12.6 \\
Monthly income/per & $910-1,818=2$ & 2 & 2.1 \\
household (\$US) & $1,819-2,727=3$ & 53 & 0.5 \\
& $2,728-3,636=4$ & 114 & 3.6 \\
& 3,637 and greater $=5$ & 237 & 12.6 \\
\hline
\end{tabular}

Though we had derived some key basic statistics (Table 2 and descriptions) that began to show some performance differences between Homeplus and Tesco, we also wished to know what were the basic criteria on which Koreans were judging these rivals. Hence we first turned to a Principal Components factor analysis (PCA) of scores on our selected attributes generated by the competing 'local' (E-mart) and 'foreign' (Homeplus) corporations in Korea. This, shown in Table 3, closely replicates work in Hallsworth (1988 p 80). The core advantage of this to the later statistical analysis is that the three derived PCA factors should be statistically independent and thus particularly suitable for regression analysis. They also provide valuable insights in their own right. An initial exploratory factor analysis was subjected to Varimax rotation (to maximise distinctive dimensions) and, from 21 individual variables, three distinct factors with an Eigenvalue greater than one emerged - with cumulative variance of around $65 \%$ and Cronbach $\alpha$ coefficients all over 0.6 . As is common 
with PCA, it is important that the variables grouped into 'factors' or 'components' do actually make sense and can viably be given an understandable label. The first and most significant derived factor, with over $33 \%$ of variance explained, we labelled "product": Zeithaml, (1988 p3) argues that "Perceived quality can be defined as the consumer's judgement about a product's overall excellence or superiority". This crucial "product" factor comprised 3 variables: 'product price', 'product excellence', and 'product reliability'. The second derived factor we labelled "convenience" and it is formed of four variables: 'convenient return and refund', 'convenient payment means', 'well-equipped rest facility' and 'convenient transportation'. The third factor we labelled "accessibility": composed of 'road convenience' and 'closeness to home'. The major implication of this part of the study was that we would need to pay particular attention to the products that were for sale at these two rivals. It does also confirm that many of the evaluative criteria work as well in Korea as in Britain - though we also needed to dig a little deeper. 
Table3 Principal Components analysis

\begin{tabular}{|c|c|c|c|c|c|}
\hline & & Cronbach's $\alpha$ & Eigenvalue & Factor loading & Variance \\
\hline \multirow{3}{*}{$\begin{array}{l}\text { Product } \\
\text { (Factor 1) }\end{array}$} & Product Price & \multirow[t]{3}{*}{.755} & \multirow[t]{3}{*}{2.986} & .831 & \multirow[t]{3}{*}{33.175} \\
\hline & Product Excellence & & & .803 & \\
\hline & Product Reliability & & & .788 & \\
\hline \multirow{4}{*}{$\begin{array}{l}\text { Convenience } \\
\text { (Factor 2) }\end{array}$} & convenient payment & \multirow[t]{4}{*}{.659} & \multirow[t]{4}{*}{1.742} & .835 & \multirow[t]{4}{*}{19.356} \\
\hline & $\begin{array}{l}\text { convenient return and } \\
\text { refund }\end{array}$ & & & .825 & \\
\hline & convenient transportation & & &. .488 & \\
\hline & Well-equipped rest facility & & & .408 & \\
\hline \multirow{2}{*}{$\begin{array}{l}\text { Accessibility } \\
\text { (Factor 3) }\end{array}$} & road convenience & \multirow[t]{2}{*}{.640} & \multirow[t]{2}{*}{1.151} & .911 & \multirow[t]{2}{*}{12.785} \\
\hline & closeness to home & & & .896 & \\
\hline
\end{tabular}

\section{Analysis of store performance Results}

As noted, the Logit model was also used for the empirical analysis of reported behaviours (see Table 4). The criteria influencing consumers' choice of store between E-Mart and Homeplus, were evaluated by local people on criteria that reflected their preferences and motivations. Importantly, we found that consumers preferring E-mart made larger purchases per visit than those at Homeplus. By calculating shop size against sales, daily averages can be calculated. They show Homeplus at 38,279 Korean won (38 US dollars) and E-mart at 49,500 Korean won (49.5 US dollars) per day. Perusal of both The Year Book of Distribution (2016) and documents produced by E-mart and Homeplus show a consistent pattern whereby Homeplus stores, of which there are slightly fewer than E-mart, are larger (typically by almost $100 \%$ ) but have lower sales densities. However, our first concern is with the evaluations that drove the spending patterns - an aspect hitherto under-emphasised.

Homeplus built or acquired larger stores that soon accommodated non-sales facilities such as 'life time education centers', beauty shops, medical centers, coffee shops, banks, restaurants, customer rest rooms etc. : this affected store sales densities. We re-emphasise 
that Factor 1 in our analysis indicated that store products were the prime evaluative factor (see again Gerhard and Hahn 2005) even though E-Mart patrons also displayed generally higher satisfaction levels regarding convenience and accessibility. At E-mart, products were seen as more authentically Korean and the Korean food shopper is well educated on quality and authenticity. Wong et al (2015) confirmed this when interviewing Korean immigrants to Vancouver, Canada. Their respondents discriminated between rival Korean-owned food chains and proactively sought out the most authentic.

Table 4 Results of the model analysis

\begin{tabular}{|c|c|c|c|c|c|}
\hline Section & $\beta$ & S.E. & Wald & Sig. & $\operatorname{Exp}(\beta)$ \\
\hline Gender & 0.209 & 0.227 & 0.843 & .359 & 0.812 \\
\hline marry & -0.272 & 0.277 & 0.968 & .325 & 1.313 \\
\hline Income & 0.035 & 0.096 & 0.129 & .720 & 0.966 \\
\hline Frequency visit & 0.020 & 0.044 & 0.211 & .646 & 0.980 \\
\hline $\begin{array}{l}\text { Purchase } \\
\text { amount }\end{array}$ & 0.540 & 0.134 & 16.310 & $.000^{* * *}$ & 0.583 \\
\hline Fac1 & 0.223 & 0.105 & 4.517 & $.034^{* *}$ & 0.800 \\
\hline Fac2 & -0.287 & 0.107 & 7.141 & $.008^{* * *}$ & 1.332 \\
\hline Fac3 & -0.234 & 0.108 & 4.661 & $.031^{* *}$ & 1.264 \\
\hline Constant & -2.570 & 0.867 & 8.782 & $.003^{* * *}$ & 13.061 \\
\hline
\end{tabular}

$*, * *, * * *$ indicates values at the $10 \%, 5 \%$, and $1 \%$ significance levels, respectively

As noted previously, and based on the recorded significance levels shown in Table 4, we find that the model identifies the Purchase amount per trip to be a key discriminatory factor between our rivals - alongside the three 'independent' PCA-derived factors. Conversely, Gender or marital status did not appear to be crucial factors. From our earlier PCA, Factor 1 
related to products and product quality and we decided to pursue this aspect further. Based on additional locally-derived insights, we found that shoppers discriminated not just on product quality/reliability but expressly on features of corporate Private Brands (PB). This is in line with studies by the Korea Consumer Agency. Overall product satisfaction cannot be ignored and simply to stress local sourcing (inevitable with fresh and perishable foodstuffs) is insufficient. It does, however, mirror the success in the UK of Aldi and Lidl which focus on price-driven PBs. In Korea, possibly reflecting sub-prime, it was through the purchase of PB products that price competitiveness (Ody 1987) emerged as a main factor and E-Mart was superior to Homeplus. Furthermore, E-Mart (15 brands, 18,000 items) also had more PB products than Homeplus (11 brands and 15,850 items). Therefore, product-related factors, notably price and quality, drove competitive superiority for E-Mart; the local corporation.

\section{A note on local product supply}

Learning from the consumer preference results has, inevitably, been our core focus but a further key topic is distribution. A major domestic strength for Tesco UK is the efficiency of its Regional Distribution Centres (RDCs). Indeed, most major UK chains moved towards Regional Distribution Centres and away from allowing local managers the discretion of local sourcing. However, it seems that Koreans prefer to 'stay local' and even PB products are delivered to large stores such as E-Mart. Inbound TNCs that are used to using RDCs need to consider how they might create relationships that allow them to source more products locally. Indeed, ALDI and Lidl did something similar in the UK. When the leading UK retailers were criticized for exploiting smaller suppliers, notably farmers, they vowed to treat such suppliers better - hardly a way to lose public sympathy. Indeed, Aldi persistently topperforms on Grocery Supply Code criteria in the UK. We also found that E-Mart generated 
higher sales per square metre from their stores than did Homeplus - a recognized truism that turned out to be, as in the UK, rather important. As UK superstores scramble to use surplus and under-performing space, in Korea, some such Homeplus space was used for the community facilities that were initially intended to make Tesco appear authentically Korean. Note that, as in Korea, over-szed stores are not favoured in Britain. Koreans evidently remain very sensitive to the value and reliability of products. Their default position is familiaritybut also authenticity. As with Wal-Mart in Germany. unfamiliar products imported by TNCs from overseas leave local consumers $100 \%$ reliant on trust in the retailer's judgement. Meanwhile, ALDI and Lidl in the UK overcame the 'tyranny of choice' (Elms et al 2016) of the vast hypermarket format with their smaller stores focusing on a narrow but keenly-priced range. Geographers Steve Wood and Jonathan Reynolds (2012) reveal analysis that can offer insights on the performance of now-popul ar smaller stores.

\section{Conclusions}

We concur with Coe, Lee and Wood (2017) that Tesco primarily withdrew from Korea in September 2015 due to domestic UK pressures. However, even though Homeplus is now relocalised, we have learned new insights on store performance: based on the 'impact' technique long familiar to retail geographers in Britain. It is satisfying that many of the evaluative criteria used in our survey worked as well in Korea as in Britain. Tesco's Korean experience allowed us to dig a little deeper and to examine impact factors that are not often covered in overseas markets. Arguably, TNCs entering similar overseas markets must make substantial adjustments to their standard operating model in order to be considered truly 'local' - and all retailers must constantly monitor their customers. As we have based our findings on a consumer questionnaire undertaken before Tesco UK sold Homeplus in 
September 2015, we encourage more consumer behaviour research. This approach is in line with the growing emphasis on 'behavioural economics' that has brought recent Nobel Prizes to both Kahneman and Thaler. The wider issue for retail geographers is, as noted in the Introduction, that the retail sector is characterized by constant change. This is not least because the global scene itself is constantly changing: often influenced by unpredictable events such as Sub-prime, Brexit or the US Presidential election. Such factors disturb preexisting assumptions about how people may behave - including how they shop and what they buy. In contemporary Britain, price-focused retailers such as Aldi and Lidl are thriving in a country where change has brought considerable uncertainty. 


\section{References}

Akehurst G and Alexander N 1996 The Internationalisation of Retailing. Frank Cass: London

Akinci S Kaynak E Atilgan E and Aksoy S 2007 Where does the logistic regression analysis stand in marketing literature? A comparison of the Market Positioning of Prominent Marketing Journals. European Journal of Marketing, 41 537-567

Arnold S 1997 Shopping habits at Kingston department stores: wave 3: three years after Wal-Mart's entry into Canada. Report No. 3, Queen's University School of Business, Kingston, July.

Bell D and Valentine G 1997 Consuming geographies Routledge: London

Bianci C 2008 Retail internationalization from emerging markets: Case study evidence from Chile. International Marketing Review, 26 221-243.

Burrows R Gilbert N and Pollert A 1992 Introduction: Fordism, Post-Fordism and Economic Flexibility. In: Gilbert N., Burrows R., Pollert A. (eds) Fordism and Flexibility. Explorations in Sociology. London :Palgrave Macmillan.

Coe NM and Lee YS, 2006. The strategic localization of transnational retailers: The case of Samsung-Tesco in South Korea. Economic Geography, 82 61-88.

Coe NM and Lee YS 2013 We've learnt how to be local: the deepening territorial 
embeddedness of Samsung-Tesco in South Korea. Journal of Economic Geography 13 327-356.

Coe NM Lee YS and Wood SM 2017 Conceptualising Contemporary Retail Divestment: Tesco's Departure from South Korea. Environment and Planning A $49 \quad 2739-2761$

Coe NM and Wrigley N 2009 (eds) The Globalization of Retailing (2 vols.). Cheltenham: Edward Elgar.

Coe NM and Wrigley N 2017 Towards new economic geographies of retail globalization. In: Clark GL, Feldman MP, Gertler MS and Wójcik D (eds) The New Oxford Handbook of Economic Geography. Oxford: Oxford University Press.

Daniel C and Hernandez T 2017 CSCA Retail 100. CSCA Research Insight. Centre for the Study of Commercial Activity, Ryerson University, Toronto, Canada.

Dicken P 1986 Global Shift London: Harper \& Row

Durand C and Wrigley N 2009 Institutional and economic determinants of transnational retailer expansion and performance: a comparative analysis of Wal-Mart and Carrefour, Environment and Planning A 41 1534-1555.

Ekinsmyth C Hallsworth AG Leonard S and Taylor M 1995 Stability and change in Economic Geography AREA 27 289-299 
Elms J de Kervenoael R and Hallsworth AG 2016 Internet or Store? An ethnographic study of consumers' internet and store-based grocery shopping practices Journal of Retailing and Consumer Services, 32 234-243.

Gerhard U and Hahn B 2005 Wal-Mart and Aldi: Two retail giants in Germany. GeoJournal, 62 15-26. Retrieved from http://www.jstor.org/stable/41147971

Goldman A Krider R and Ramaswami S 1999 The Persistent Competitive Advantage of Traditional Food Retailers in Asia: Wet Markets' Continued Dominance in Hong Kong Journal of Macromarketing 19 126-139

Hallsworth A G 1988 The Human Impact of Hypermarkets and Superstores Gower Press, Aldershot.

Hallsworth A G 1991a The Campeau takeovers: the arbitrage economy in action Environment and Planning A 23 1217-1223.

Hallsworth AG 1991b Accessibility of food stores - a case study British Food Journal 93 29-40.

Kim WH and Hallsworth AG 2013 Large format stores and the introduction of new regulatory controls in South Korea. The International Review of Retail, Distribution and Consumer Research, 23 152-173. 
Kim WH and Kim H 2013 A Local Economic Development Strategy: Evidence from Traditional Market Districts. The Journal of Small Business Innovation, 16 1-18.

Korea Chain Store Association 2011, 2016 The Yearbook of Retail Industry (www.koca.or.kr)

Korea Statistics 2013 (http://kostat.go.kr).

Nobbs K Moore CM and Sheridan M 2012 The flagship format within the luxury fashion market International Journal of Retail \& Distribution Management 40 920934 https://doi.org/10.1108/09590551211274928

Ody P 1987 The Growth in Private Brands Retail \& Distribution Management, 15 9-11.

Pattnaik C and Lee J-Y 2013 Distance and divestment of Korean MNC affiliates: the moderating role of entry mode and experience. Asia Pacific Business Review (http://tandfoline.com/loi/fapb20)

Scott P 1970 Geography and retailing. Hutchinson: London

SMBA Small and Medium Business Administration 2012 Comprehensive plans for the revitalization of the traditional market (www.smba.go.kr).

The Year Book of Distribution 2016 Year Book of Distribution. Korea. 
Wong A Hallsworth AG and Choi C 2015 Of Kimchi, Caribou - and Canadian

Multiculturalism? An exploratory study. Ethnology and Anthropology 10 311-331

Published online: 6 August 2015.

Wood SM and Reynolds J 2012 Leveraging locational insights within retail store development? Assessing the use of location planners' knowledge in retail marketing Geoforum 43 1076-1087

Wood SM Coe NM and Wrigley N 2016 Multi-scalar localization and capability transference: exploring embeddedness in the Asian retail expansion of Tesco. Regional Studies 50 475-495.

Wrigley N 1988 Retail restructuring and Retail Analysis. Chapter 1 in Wrigley N (ed) Store Choice, Store location and Market Analysis Routledge: London

Wrigley N and Dolega L 2011 Resilience, fragility, and adaptation: new evidence on the performance of UK high streets during global economic crisis and its policy implications Environment and Planning A, 43 2337-2363.

ZeithamI VA 1988 Consumer Perceptions of Price, Quality, and Value: A Means-End Model and Synthesis of Evidence Journal of Marketing 52 2-22 